\title{
TODOS OS PRIVILEGIADOS DEVEM SER PREMIADOS*
}

JOHN H. SUMMERS

TRADUÇÃO: OTACÍLIO NUNES JR.

[*] Artigo publicado em The Times of Higher Education em 10 de julho de 2008. Uma versão mais extensa deste texto incluirá a coletânea Every fury on earth, de John H. Summers, a ser publicada em agosto de 2009.
Ingressei na equipe do Comitê de Títulos em Estudos Sociais da Universidade Harvard em 2000. Como tutor, depois professor, orientei teses de formandos, concebi e conduzi seminários para calouros e estudantes do penúltimo ano e lecionei seis vezes o tutorial com um ano de duração para segundanistas, Social Studies 10. A natureza fraturada de minha nomeação, renovada anualmente por seis anos seguidos embora em nenhum ano atingindo mais de $65 \%$ de um cargo em tempo integral, manteve-me à margem do prestígio e da promoção ao mesmo tempo em que me fez permanecer lá tempo suficiente para trabalhar com três catedráticos de estudos sociais, dois diretores de estudo e três presidentes de Harvard.

Entre os filhos pós-pubescentes de notáveis, dos quais me vi assumindo a responsabilidade curricular, incluíam-se os descendentes de uma importante figura política, de um importante empresário do mundo do show business e o filho do incorporador imobiliário Charles Kushner.

Na primeira reunião de meu primeiro seminário do primeiro ano em que estive lá,Jared, o filho de Kushner, entrou na sala de aula e prontamente sentou no lugar em frente ao meu, partilhando comigo, por assim dizer, a sala. Eu ganhava um salário anual de US $\$ 15.500$ e tomava emprestado o restante para sobreviver em Cambridge, para que ele pudesse ter a melhoreducação possível.Jared mais tarde comprou o The New York Observer por US $\$ 10$ milhões, ganhos em parte, com compra e venda de imóveis na mesma época em que freqüentava meu seminário. Como editor, uma de suas primeiras medidas foi reduzir o pagamento do grupo de resenhadores de livros desse jornal. Eu escrevia resenhas para o Observer em um esforço para pagar minhas dívidas.

A maioria dos estudantes que encontrei em Harvard havia já abraçado as perspectivas dos ricos, dos poderosos e dos não alienados, e 
parecia tê-lo feito com uma facilidade espantosa. Seguindo a tradição dos ricos norte-americanos, eles trabalhavam por períodos excepcionalmente longos, eram agressivos no exercício de seus talentos e unânimes a respeito das características ideológicas do capitalismo de mercado. Seus trabalhos escritos revelavam os componentes centrais do consenso adotado por seus pais: o significado da liberdade reside na escolha pessoal dos consumidores; a livre concorrência em bens e padrões de comportamento regula o valor; o progresso tecnológico é um bem puro; a guerra é lamentável.

Em torno desse consenso cristalizava-se um ethos. Um de meus alunos menos abastados, filho de um carteiro, pediu-me certa vez conselho sobre um investimento financeiro. Disse ele que seus amigos haviam sugerido que ele investisse "em prisões", isto é, numa das empresas privadas que ganhavam contratos de administração de presídios. Eu lhe disse o que pensava sobre essa recomendação; mas só depois, quando fui informado de quão pouco ele pretendia investir (sua poupança total era de US\$2 mil), eu me permiti pensar que entendia o significado de sua pergunta.

Não se pode permitir que nenhuma quantidade de dinheiro fique ociosa se algo pode ser conseguido de graça. A teoria capitalista da vida como um jogo desautoriza vantagens não capitalizadas.

Perguntei a todos os participantes de meus seminários sejá haviam encontrado um professor que apreciassem genuinamente. Se sim, quais aspectos eles mais admiravam? Invariavelmente eles diziam que bons professores os faziam "sentir-se à vontade". Para sentir a esterilidade era preciso ouvir: "período de compras" era o nome da semana em que eles escolhiam as matérias. Uma vez, quando propus dar um seminário para os estudantes do penúltimo ano, intitulado "Crítica cultural anarquista na América", fui instruído a só levá-lo adiante se primeiro mudasse o título para "A América e seus críticos". Aqui estava o mesmo método de higiene cultural que transformou a Harvard Square de um enclave boêmio em um shopping aberto.

A atribuição de notas, o único instrumento de poder de que eu dispunha, oferece o melhor exemplo da degradação da pedagogia pelo frenesi do sucesso. A exposição pelo Boston Globe da inflação de notas em Harvard deixou pouca dúvida de que ela é uma competição semimanipulada, outro risco subvencionado. Aescala formal vai de A a F.A escala tácita vai de A a B. Aprendi esta última de alunos e supervisores, mas especialmente de colegas, poucos dos quais desejam carregar o opróbrio do resultado inferior. Isso é o que pode ser. Mas a presença de dois padrões de valor, um oficial e um tácito, é sempre um sinal de corrupção: um necessariamente desgraça o outro. E também abrevia a liberdade acadêmica do professor. Embora eu nunca tenha dado uma nota final abaixo de B-, posso atestar o assédio mesquinho que os pro- 
fessores atraem nesses casos. Não estou dizendo meramente que os alunos nunca são tão agressivos e articulados como quando caçam notas. Estou dizendo que eles executam represálias políticas contra o professor que atribui notas B- e mandam presentes para diretores acadêmicos situados nas altas esferas.

Certa vez, um juiz e sua mulher foram falar com meu supervisor para se queixar de uma nota que eu dera ao filho deles em um exame oral do último ano. Eles baseavam a queixa no fato de que eu ainda não estava na posse plena da credencial abrangente, o Ph.D. Observaram que o segundo examinador na sala tinha atribuído ao exame uma nota um pouco mais alta, e que esse segundo examinador era, de fato, um Ph.D. O juiz e a mulher não sabiam, nem se preocuparam em descobrir, que eu era de longe o mais experiente dos dois examinadores. Eu conduzia exames havia quatro anos; o segundo examinador nunca havia conduzido um. Uma gafe menor, mas uma que William James, autor de "O polvo Ph.D." (1903), poderia ter entendido e apreciado.

Em janeiro de 2008, um "grupo de alunos de Harvard da época da Guerra do Vietnã" enviou uma carta aberta ao presidente da universidade. "Estamos preocupados com o que vemos como a apatia e a indiferença política generalizadas do corpo estudantil na Harvard College hoje", dizia a carta (reportada na Times Higher Education em 4 de janeiro de 2008), que definia o problema como "auto-exame e amplo crescimento intelectual versus orientação vocacional carreirista". A carta não estava totalmente correta: os estudantes são o oposto de apáticos e indiferentes. Os novos ricos estudantes conservaram a energia radical dos anos de 1960 apenas para empregá-la em competências mais exuberantemente monetizadas. A Nova Esquerda ocupou universidades para protestar contra a obtusidade burocrática dos rituais de exame e as justificativas para as notas. Agora seus filhos completam o ataque à autoridade dos professores, que são simplesmente anexados à administração das carreiras dos alunos, arrastados para um acordo tácito entre corporação e cliente no qual não existe a opção do fracasso. Eu tinha de atribuir notas aos alunos, e notas boas. Todos esperavam uma carta de recomendação.

O ethos, assim entendido, imita a psicodinâmica da inflação nesta época de mercados ilimitados. Como os alunos eram jovens, aparentemente, seus pais e professores os banharam em olhares ambiciosos, de forma que a fonte da própria identidade deles passou a repousar sobre seu potencial. Talvez seja por isso que eles, embora exijam receber notas, se ressintam da reivindicação do professor a um julgamento baseado em desempenho, o que implica um conjunto estável de valores. Um julgamento relativamente baixo pode ser enfrentado com o pensamento sempre disponível de que eles poderiam ter se saído melhor. 
Esse pensamento não é fácil de refutar como se poderia supor. Os alunos de Harvard podem ser divididos em três tipos. Aqueles que inferem, de sua presença no campus, que já alcançaram o sucesso e aqueles que acreditam estar a caminho de alcançá-lo. Ambos têm uma consciência aguda do prestígio de sua situação. Mencionar a um estranho onde se estuda tem o efeito de uma "Bomba H". Nenhum desses dois tipos encontrou uma razão realmente boa para supor que seu potencial é qualquer coisa menos que ilimitado. Já os que pertencem à terceira categoria - irônicos e gozadores - têm seu título e também o comem, uma vez que sua postura anti-Harvard não comporta nenhum risco real.A dotação gigantesca, esse grande símbolo de potencial não utilizado, abençoa o ceticismo deles, indexando-lhes o valor no mercado de credenciais.

Considere como o escândalo das notas (um segredo aberto no campus) entrou na discussão pública ao mesmo tempo em que a bolha de aumentos de preços das ações das empresas de tecnologia explodiu. Tentever esses fenômenos como exemplos gêmeos na superexpansão crônica dos mercados de crédito. Agora faça a pergunta: quando intelectuais agem como balconistas e alunos agem como clientes, em que os professores universitários diferem de contadores de empresa?

Devo dizer que sou grato pela oportunidade de lecionar em Harvard? Devo. Devo reconhecer as ótimas exceções que tive o privilégio de instruir? Reconheço, com prazer. Mas a banalidade diligente dos ricos degrada o ensino em uma preocupação com uma aula-serviço cujo principal dever é preparar clientes para carreiras endinheiradas. A bajulação liberal do aluno é tanto sentimental como irrelevante. Se a juventude é desperdiçada nos jovens, o ensino é desperdiçado nos alunos?

Lecionar em tempo parcial em Harvard é um pouco como visitar o Disney World. A poeira mágica induz uma leve narcose. A mente torna-se incontinente na presença do paradoxo e do conflito, eé difícil distinguir quanto você está se divertindo de quanto está tendo de fingir. O importante é nunca se tornar o histérico que estraga o passeio de todos. A fila é comprida.

JOHN H. Summers é pesquisador visitante no Boisi Center for Religion and American Public Life, Boston College, e editor de The politics of truth: selected writings of C. Wright Mills, a ser publicado em setembro de 2009. 